\title{
Muralf
}

INTERNACIONAL

Mural Internacional

V. 7 | N. 2

JUL-DEZ 2016

\section{Embaixador Sérgio Tutikian: um pioneiro Oriente Médio \\ Ambassador Sérgio Tutikian: a pioneer in the Middle East}

\section{MONIQUE SOCHACZEWSKI GOLDFELD ${ }^{1}$}

Resumo: Sérgio Tutikian é um pioneiro por dois motivos: por um lado é dos primeiros diplomatas de origem armênia nos quadros do Ministério das Relações Exteriores e por outro é o primeiro a de fato ter servido nos postos-chave do Oriente Médio, dominando muitas de suas línguas, aspectos culturais e sensibilidades políticas. O depoimento em questão é uma entrevista de História Oral, do tipo história de vida, em que o entrevistado conta sobre a história da chegada da sua família ao Brasil, no contexto das perseguições porque os armênios passaram no Império Otomano em sua fase final, perpassa o estabelecimento da mesma no Rio Grande do Sul, sua escolha não óbvia pela carreira diplomática, e centra-se então em seus testemunhos sobre passagens no Irã, Iraque e Kuwait, entre outras localidades médio-orientais.

Palavras-chave: Diplomacia; Armênios; Diáspora; Oriente Médio.
Recebido em:

09 de Novembro de 2017

Received on:

November 09, 2017.

DOI: 10.12957/rmi.2016.31421

Abstract: Sérgio Tutikian is a pioneer for two reasons: on the one hand, he is one of the first diplomats of Armenian origins in the Brazilian Ministry of Foreign Affairs, and on the other hand he is the first one to have served in the key posts of the Middle East, mastering many local languages, cultural aspects and political sensitivities. The testimony here is an Oral History interview, in which the deponent shares the story of the arrival of his family in Brazil - in the context of persecutions the Armenians suffered in the last phase of the Ottoman Empire -, their settlement in Rio Grande do Sul, his non obvious choice for the diplomatic career, and then focuses his testimony on events he witnessed in Iran, Iraq and Kuwait, among other Middle Eastern places.

Keywords: Diplomacy; Armenians; Diaspora; Middle East.

\footnotetext{
${ }^{1}$ Doutora em História, Política e Bens Culturais pelo CPDOC/FGV e Professora do Programa de Pós-Graduação em Ciências Militares da Escola de Comando e Estado-Maior do Exército (ECEME). E-mail: moniquesgoldfeld@ gmail.com
} 
O Brasil conta com uma diáspora armênia de cerca de quarenta mil integrantes, largamente localizada na cidade de São Paulo. Para além dos textos de memória escritos por integrantes da própria comunidade ou a seu respeito, ganha força nos últimos tempos relevantes pesquisas acadêmicas sobre esta, que envolvem domínio do idioma e pesquisa de campo em Yerevan. É esse o caso dos trabalhos de Pedro Bogossian Porto, com pesquisa antropológica sobre os cristãos ortodoxos armênios em São Paulo (Porto, 2015), e de Heitor Loureiro, com tese em História recém-defendida sobre a política externa brasileira e a causa armênia entre 1912 e 1922 (Loureiro, 2016).

A entrevista com o embaixador Sérgio Tutikian que aqui se apresenta, pode ser entendida por um lado como parte desse esforço de melhor conhecer a trajetória da diáspora armênia no Brasil. Sua trajetória, porém, destoa ao não estar centrada em São Paulo ou em atividades mais tradicionais ligadas a essa diáspora, como o ramo de fabricação e venda de calçados (Grün, 1992; Paverchi, 2015). Trata-se de um gaúcho com larga experiência diplomática, sendo o pioneiro a de fato servir amplamente e dominar profundamente as peculiaridades do Oriente Médio

Ainda no Império Otomano, sobretudo no século XIX, houve casos de armênios que seguiram a carreira diplomática atuando pelo império multiétnico, multilinguístico e multicultural que este ainda se mostrava. Esse foi o caso, por exemplo, de Artin Dadyan Paxá, que chegou a subsecretário do ministério das relações exteriores otomano no sultanato de Abdul Hamid II (r. 1876-1909) e que tinha parentesco com um dos primeiros armênios a imigrarem para o Brasil, Mihran Latif (Sochaczewski 2017, p. 247). A opção de Sérgio Tutikian pela diplomacia, porém, não se deu originalmente por uma tradição armênia, mas por outras conexões de amizade com parentes de diplomatas brasileiros ou servindo no Brasil, como se verá na entrevista a seguir. No Itamaraty, porém, conviveu com um grupo de diplomatas com a mesma origem.

Suas origens armênias, contudo, bem como os conhecimentos linguísticos por conta desta (como o próprio armênio e o turco), certamente se mostraram ferramentas úteis em sua atuação no Oriente Médio. Justamente quando a região entrava na órbita da diplomacia brasileira, sobretudo no contexto dos choques do petróleo nos anos 1970, Sérgio Tutikian começava carreira na região. Atuou com xiitas e com sunitas, em missões à própria região ou em outras regiões do mundo a seu respeito, e estudou-a com afinco.

Quando da presidência de Luiz Inácio Lula da Silva (2003-2010), o Oriente Médio voltou a ter nova ampla atenção do governo brasileiro. O chanceler Celso Amorim já publicou largamente a esse respeito (Amorim, 2015) e, aparentemente, sua estratégia para a região dentro do Itamaraty envolvia fazer com que alguns embaixadores servissem em diversas embaixadas da região - como foi o caso, por exemplo, de Cesário Melantônio Neto, 


\section{Muralf INTERNACIONAL}

que serviu no Irã, Turquia e Egito; e de Antônio Luis Espínola Salgado, que atuou no Irã e depois na Turquia - e estimular entre o corpo diplomático o estudo de línguas como o árabe ${ }^{2}$. Vale notar aqui, porém, que Sérgio Tutikian já era um precursor nesse sentido, não só tendo servido em diversas embaixadas da região, como Irã, Iraque e Kuwait, como aprendendo in loco também o persa e o árabe.

Sérgio Tutikian já deu algumas entrevistas para a imprensa sobre sua trajetória ${ }^{3}$ e, apesar de se dedicar ao magistério superior em Porto Alegre, desde a sua aposentadoria há uma década, não publicou nenhum livro de memórias ou algo correlato. Por conta da peculiaridade de sua trajetória, tanto como um membro da diáspora armênia que seguiu carreira diplomática de alguma forma conectada às suas origens, como por ser um precursor a servir em tantas embaixadas e missões importantes no Oriente Médio, considerou-se aqui a validade de uma entrevista extensa com o mesmo. A entrevista integra um esforço mais amplo de apreender a trajetória das diásporas do Império Otomano no Brasil, as relações do

\footnotetext{
${ }^{2} \mathrm{O}$ estímulo do MRE se dava para idiomas como russo e chinês, além do árabe. O diplomata interessado em algum desses idiomas passava então um ano estudando exclusivamente a língua em questão in loco, sem que esse período contasse como tempo de posto.

${ }^{3}$ Ver, por exemplo, "Com a palavra: Sérgio Tutikian". Zero Hora, 25/3/2014. [online]. Disponível em: http://videos.clicrbs.com.br/rs/zerohora/video/geral/2014/03/ com-palavra-sergio-tutikian-embaixador-brasileiro-queserviu-iraque-saddam-hussein/70043/. [Acesso em 28/10/2017].
}

Mural Internacional

V. 7 | N. 2

JUL-DEZ 2016
Brasil com o Oriente Médio, bem como o papel das primeiras sobre as segundas. $\mathrm{O}$ método usado foi o de História Oral, na modalidade História de Vida (Alberti, 2004), e a entrevista foi realizada por Skype, em 22 de setembro de 2017, com a entrevistadora no Rio de Janeiro e o entrevistado em Porto Alegre.

MS - Embaixador, por favor, conte sobre a história de seus pais, que eram de origem armênia e vieram para o Brasil no contexto da fase final do Império Otomano.

$S T$ - Sou filho de primeira geração por parte de pai. Ele, que se chamava Barkev (que em armênio quer dizer dádiva), nasceu na Anatólia Central, em Gemerek, província de Sivas, hoje na Turquia. Ele teve a família massacrada em 1915. Salvaram-se apenas um irmão e uma irmã. A irmã tinha 9 anos, ele, 7 e o irmão menor, 4 anos. Eles foram salvos por uma família turca piedosa que os acolheu em sua casa, e, posteriormente, os entregou para missionários norteamericanos, que acho que eram da Igreja Episcopal. Os meninos foram levados para um orfanato em Beirute, no Líbano. Imagino que você saiba que o Líbano foi criado justamente para receber os cristãos perseguidos pelo Império Otomano. Lá foram levados para um orfanato norteamericano, dirigido por armênios. A irmã foi levada também para um orfanato norteamericano na Grécia, aonde pouco depois veio a falecer "de melancolia". Meu pai e meu tio ficaram nesse orfanato até completarem 20 anos. Meu pai, ao completar 20 anos deixou o orfanato e foi 
trabalhar como agrimensor para os franceses no Estado Alauíta ${ }^{4}$, hoje Síria, para juntar o dinheiro da passagem para vir para o Brasil. $O$ irmão continuou no orfanato esperando que meu pai mandasse o dinheiro para ele também vir ao Brasil, o que aconteceu dois anos depois. Inicialmente a ideia de meu pai era a de emigrar para a Austrália. Na verdade meu pai embarcou para o Brasil como apátrida, com um documento de viagem emitido pela França, país mandatário do Líbano e do Estado Alauíta. No Brasil ele escolheu o Rio Grande do Sul porque o clima era mais parecido com o de sua cidade natal. Ele chegou a Porto Alegre em 1928.

\section{MS - E qual a história do lado de sua mãe?}

$S T$ - A família da minha mãe foi vítima dos massacres perpetrados pelo sultão Abdul Hamid II, no final do século XIX. Meus avós eram da Cilicia ou Petite Arménie. Ele era de Antióquia (hoje Antakya), berço da cristandade, e ela de Alexandreta (Iskenderum), ambas atualmente parte na província turca de Hatay, no Mediterrâneo Oriental. Era uma família abastada de armadores e fugiram em um de seus navios para o Egito. Viveram em Alexandria por aproximadamente quatorze anos e chegaram ao Brasil em 1912, estabelecendo-se em São Paulo. Ali se juntaram aos Keutenedjians, e aos Gasparians com quem

\footnotetext{
${ }^{4}$ Os alauítas são uma minoria religiosa islâmica, muito influentes politicamente na Síria. A família Assad, no poder desde a década de 1970, é alauíta. [N.E.]
}

eram aparentados. Minha mãe nasceu no Brasil e chamava-se Olga. Falávamos armênio e o português foi para minha irmã e para mim uma língua aprendida. A língua turca era falada quando meus avós e meus pais não queriam que entendêssemos o assunto. Nós falávamos armênio também com nossos avós. As noções elementares que adquiri da língua turca auxiliaram-me muito no início de minha carreira. Meu primeiro posto foi Teerã e naquela época o turco era a segunda língua mais falada no Irã.

\section{MS - E como se deu o casamento deles?}

$S T$ - Naquela época cada um queria casar dentro de seu grupo étnico-religioso. E meu pai foi a São Paulo procurar uma noiva. A igreja armênia ajudava colocando em contato moças casadouras. Eles se casaram entre 1934 e 1935. Na época era habitual entre os judeus, gregos e armênios, oriundos do Império Otomano casar-se no civil, depois de acertados os pormenores com os pais da noiva, e só depois que o noivo se considerasse financeiramente pronto realizar o casamento religioso e consumálo. Fixaram residência em Porto Alegre, onde eu nasci. Eu tenho mais quatro irmãos.

\section{MS - E como seu pai se sustentou?}

$S T$ - Inicialmente com pequeno comércio. Embora ele tivesse recebido uma excelente educação no orfanato norte-americano, e nesse sentido sempre foi muito grato à generosidade norte-americana. Apesar de ele ser de nascimento cristão ortodoxo, sua formação sofreu grande influência da 


\section{Muralf}

INTERNACIONAL
Mural Internacional

V. 7 | N. 2

JUL-DEZ 2016 religião protestante. Chegado ao Rio Grande do Sul, além de aprender o português, ele teve de aprender o alemão também, muito falado na época. Ele foi muito ajudado, principalmente por comerciantes e industriais alemães ou de ascendência alemã. Meu pai gozava de uma reputação muito boa na cidade. $\mathrm{E}$ com isso ele conseguiu deixar de ser pequeno comerciante e tornando-se num primeiro momento dono de uma modesta confecção e para posteriormente tornar-se industrial no ramo da tecelagem. Ele morreu precocemente em um trágico acidente.

\section{MS - Existia uma comunidade armênia em} Porto Alegre?

$S T$ - Muito pequena e era basicamente de colegas oriundos do mesmo orfanato. O meu pai chegou primeiro e aí ele começou a trabalhar para que os outros também viessem para Porto Alegre. A comunidade não passava de seis ou sete famílias. Uma vez estabelecidos mandavam vir suas futuras mulheres ou de Istambul, Bolis em armênio (a Polis) depois. Era "a cidade". Em geral quem viesse de Istambul tinha mais cultura, falavam o turco culto. Algumas dessas senhoras não conseguiam mais falar armênio porque tinham sido educadas em uma época em que fora proibido o uso da língua armênia no Império Otomano. Eu me lembro de quando eu era pequeno - de reuniões sociais que incluía judeus de sefaraditas de Istambul (os Rodriguez, os Behar) que acabavam sempre em choradeira, pois eles sentiam nostalgia da língua turca, da música e da dança. Afinal era o "país" deles, era a língua de todo dia. Os armênios e os judeus se juntavam para falar das saudades e nessas reuniões eles cantavam e dançavam. Lembro-me da família Behar, cuja filha, Elisa Behar, foi "Glamour Girl" e depois Miss Porto Alegre. Eles falavam ladino ou turco.

\section{MS - No final do Império Otomano,} muitos missionários católicos e protestantes conseguiram converter os armênios. Era esse o caso da sua família?

ST - A comunidade de Porto Alegre era basicamente ortodoxa e discriminava os protestantes. A maior cisma de minha avó materna era justamente porque o meu pai tinha algumas ideias protestantes. Foi educado pelos protestantes, como eu disse, e se sentia devedor deles. Inclusive ele pediu que, se ele não pudesse, que um de nós educássemos, do primeiro ano primário até o último ano da faculdade, pelo menos quatro crianças necessitadas, o que já fiz em parte.

\section{MS - O seu pai falava dos turcos?}

$S T$ - Ele se recusava a falar sobre os turcos ou na língua turca. Não falava nada sobre o que tinha acontecido. $\mathrm{O}$ pouco que eu sei foi o que me foi transmitido por meu tio. Talvez ele tenha sofrido menos trauma por ser mais jovem. Meu pai nunca falava nada. Era um silêncio sepulcral. Outro dia eu li nas redes sociais um manifesto de um grupo de escritores turcos dizendo que sentiam muito pelo o que ocorrera com os armênios no passado, pedindo desculpas. É óbvio que não apaga o passado, mas faz bem esse 
pedido de desculpas. Os turcos não admitem que houve genocídio, mas aceitam a palavra massacre. Dizem que a população turca também sofreu os efeitos da guerra. Mas você sabe que não é bem assim. A Alemanha e a Áustria, aliadas do Império Otomano, também tem sua parcela de culpa; mas pediram desculpas recentemente.

MS - Embaixador, pode falar agora como foi sua formação em Porto Alegre até a ida para o Itamaraty?

$S T$ - Eu fui alfabetizado em um colégio católico. Por insistência da minha avó materna e porque aqui não havia Igreja Ortodoxa Armênia, minha mãe acabou me batizando na Igreja Católica, onde também, com apenas cinco anos de idade, fiz a primeira comunhão. Depois eu fui transferido para um colégio metodista que se chamava Porto Alegre College e que atualmente se chama IPA, Instituto Porto Alegre. Um dos reitores e alguns professores dessa escola vinham dos EUA e eram da Igreja Metodista. O meu pai queria que eu fosse engenheiro, porque ele tinha estudado algo do ramo em Beirute. $\mathrm{Eu}$ ia cursar Engenharia, mas a contragosto. Aconteceu, porém, que três colegas que eram filhos de diplomatas conseguiram influenciar-me. Um era filho do cônsul da Alemanha em Porto Alegre, o Uwe Bertrand. E os outros dois eram filhos de um diplomata brasileiro que era Embaixador do Brasil, na época, na Bélgica. Ele mandara os filhos para o Brasil para concluir o Ensino Médio e desse modo aprenderem português, geografia e história do Brasil. Eram Manoel Maurício Cardoso Palmeiro e Joaquim Cardoso Palmeiro. Eles me convidaram para irmos juntos pedir informações sobre a carreira no Rio de Janeiro. Naquela época tudo era muito difícil, porque não havendo internet, boas livrarias, e bons jornais aqui em Porto Alegre as informações ou não chegavam ou tardavam muito a chegar. Formei-me em Direito pela UFRGS. O exame de admissão ao Instituto Rio Branco era muito mais trabalhoso, complexo, do que agora, pois além do que é pedido agora incluía língua e literatura inglesa, francesa e portuguesa. $\mathrm{Eu}$ fui muito desestimulado pela minha família. Eles diziam que eu não passaria nunca e se fosse aprovado nunca chegaria a Embaixador, já que não tinha linhagem na Carreira diplomática. Prestei vestibular, fui aprovado e, minha turma que era de 26 alunos só sete chegaram a Embaixador. Foram eles que me levaram para a Carreira Diplomática.

\section{MS - Já havia armênios no Itamaraty então?}

$S T$ - Não havia. Os primeiros a entrar foram eu e Ademar Bahadian. Até então não havia diplomatas de ascendência armênia. Ingressei no Itamaraty em 1965. Isso tudo coincide com o Regime Militar. $\mathrm{Na}$ realidade quem abriu as portas do Itamaraty para a classe média foram os militares. Foram eles que "democratizaram o MRE”. Até essa data não havia judeus, afrodescendentes, ou filhos de primeira geração. Até essa data só entravam em sua grande maioria membros de famílias 


\section{Muralf}

INTERNACIONAL

Mural Internacional

V. 7 | N. 2

JUL-DEZ 2016

tradicionais e com nomes pomposos. Se você pegar uma lista de antiguidade da época, você vai ver isso. Éramos novidade no Brasil. Sempre houve e há diplomatas armênios nos diferentes corpos diplomáticos estrangeiros. Segundo o "Foreign Policy Institute" de Ancara, publicação "The Armenian Issue in nine questions" publicada em 1982, afirma que no século XIX havia sete Embaixadores, onze Cônsules Gerais e um Ministro dos Negócios Estrangeiros a serviço do Império Otomano. Será um talento inato desse povo?

\section{MS - E quem eram esses outros armênios?} Vocês se davam entre si?

$S T$ - Eu não sei se vou conseguir me lembrar de todos, mas vamos lá. Tinha a Gilda Ohanian, o Ademar Bahadian, o Michel Arslanian, o Regis Arslanian, o Sarkis Karmirian, a Helena Gasparian e outros dois mais com nomes arabizados que se diziam armênios. A gente não se conhecia. Só algum tempo depois fizemos amizade. Isso tem a ver com as peculiaridades do serviço exterior, porque ficávamos muito tempo fora, servindo em postos diferentes. Uma ocasião, porém, minha mãe resolveu oferecer um almoço a um escritor norte-americano de ascendência armênia e achou oportuno reuni-los em minha casa. Mas nunca coincidia de estarem todos em Brasília na mesma época. E havia diferenças entre os armênios. Uns vinham do interior da Turquia e não tinham um armênio muito sofisticado. Outros vinham da França...
$M S$ - E no Itamaraty o senhor chegou a servir na Turquia?

$\boldsymbol{S T}$ - Em missões transitórias sim, mas nunca servi na Turquia ou em nenhum desses países de expressão uralo-altaica. Eu fui a uma missão à Turquia em 1987, com a Helena Gasparian. Nós fomos a Istambul e depois, a Ancara, mas em missão administrativa do Itamaraty. Na capital Ancara, Helena quis ver uma falci (as mulheres que olham a sorte na borra do café), que previu que ela iria se casar novamente e ter mais filhos, e isso realmente aconteceu. (risos) Os turcos foram muito corteses conosco e eu não sei exatamente porque o Itamaraty nos mandou. Eu acho que foi para fazer graça. Eu não dizia nada, mas a Helena reclamava abertamente sempre que oportuno que tomaram nossas terras, e massacraram nossos familiares. Como não estávamos lá em missão permanente, isso não tinha importância. No Kuwait, foi o oposto, porque coincidiu com o tempo em que um grupo terrorista armênio assassinava diplomatas turcos e o embaixador da Turquia pedia sempre para me dar o braço (não sei se por medo ou para fazer graça) e eu dava a ele e dizia: "Não faz mal. Vocês salvaram o meu pai e então pode vir".

\section{MS - E com a Armênia, o senhor tinha relações?}

$S T$ - Olha, eu tinha parentes lá porque uma parte da minha família conseguiu fugir pela fronteira da Rússia e foi para lá. Depois, porém, conseguiram ir para o Canadá e para os Estados Unidos. A maioria de 
minha família está nos Estados Unidos. Estavam em Newark e Los Angeles, mas perdemos o contato. $\mathrm{Na}$ ocasião, os que ficaram na Armênia me convidaram para visita-los, mas era na época da ditadura e a Divisão de Segurança do Itamaraty disse que não, para que eu não fosse. Até porque eu não sei se você sabe, mas nós ficamos com duzentos brasileiros lá. Houve em determinado momento uma propaganda muito grande da União Soviética na região do Paraná, para atrair pessoas de ascendência ucraniana e russa. E alguns iludidos emigraram para lá. Chegaram e viram que aquele sonho não se concretizara. Eles quiseram voltar, mas, do grupo, duzentos não conseguiram permissão para voltar, já que tinham se envolvido com assuntos militares. E lá ficaram. Eu tinha receio que invocassem o jus sanguinis $^{5}$ e não me deixassem sair da União Soviética. Era a época da Guerra Fria. Não insisti e achei melhor mesmo não ir. Até porque não me dizia nada. As minhas raízes profundas, as tradições e a comida, estavam na Armênia Otomana, atual Turquia. Ademais a língua que eu falava era diferente. Como você sabe há o armênio ocidental, falado no antigo Império Otomano, e o, armênio oriental, e eu tenho dificuldade com o armênio oriental, que é o que se fala atualmente no Irã e na Armênia.

\footnotetext{
5 Doutrina jurídica pela qual o direito de cidadania é conferido pelos pais serem daquela nacionalidade, contrapõe-se ao jus solis, pelo qual é cidadão quem nasce no país em questão. O jus sanguinis é comum na Europa e no Oriente Médio; o jus solis, nas Américas. [N.E].
}

MS - Então fale agora como se deu sua passagem pela embaixada do Brasil em Teerã?

$S T$ - Eu estive no Irã duas vezes. Foi o meu primeiro posto como Secretário de Embaixada e foi o meu primeiro posto como Embaixador. A primeira vez que eu fui para o Irã, ainda era na época do Xá. Fui muito feliz lá. A embaixada era apenas uma embaixada de representação naquela época, nos anos 1970, e não havia muito que fazer. Você sabe que nesta época o Brasil era muito dependente do petróleo externo, pois não o produzíamos então, e a OPEP foi criada em 1973 e o Irã era um importante exportador de petróleo. Fui aconselhado por alguns colegas a estudar persa e árabe e aprender tudo que pudesse sobre petróleo. Domino o persa, mas o árabe eu não consigo tão bem. Na verdade são três línguas: o árabe clássico (língua escrita), o árabe da TV e o árabe local em cada país. E língua semita é muito difícil para nós que somos de língua indo-europeia. Já o persa é muito fácil porque é indo-europeia. Você aprende rapidamente. Mas, enfim, consigo falar um árabe clássico, me faço entender, mas faz mais de vinte anos que não uso. Já o persa, além de ser próximo do armênio, fica mais fácil por ter muitos vocábulos de origem turca, língua que eu sempre soube um pouco. Eu estudei persa e árabe na Universidade Meli de Teerã. O mais difícil para mim foi o alfabeto que é o árabe, acrescido de mais cinco letras. A minha ida para o Irã foi acidental e eu fui por razões pessoais. Quando você se forma no Itamaraty, normalmente no início da 


\section{Muralf}

INTERNACIONAL
Mural Internacional

V. 7 | N. 2

JUL-DEZ 2016 carreira somos mandados para uma grande Embaixada onde se possa usufruir da experiência dos colegas mais antigos. E eu fui para uma em que eu ficava praticamente sozinho, pois era Chargé d'affaires a maior parte do tempo em Teerã. Mas eu havia passado por um teste de fogo, que foram três meses na Bolívia como Chargé d'Affaires e o Itamaraty considerou que eu podia assumir a chefia no Irã. E eu só podia ir para Posto $\mathrm{C}$ porque eu não tinha completado o estágio regulamentar. Isso foi em 1970, quando o Presidente Médici baixou decreto em que, entre outras coisas, exigia que o MRE fosse o primeiro Ministério a mudar-se para Brasília. E aí para não ir para Brasília, eu fui parar em Teerã. Lá encontrei um Chefe extremamente competente, bom e refinado, o Embaixador Antônio Borges da Fonseca. Sou padrinho de casamento de sua filha mais jovem, Eliana.

MS - E aí o senhor ficou quanto tempo nesse primeiro posto no Irã?

$S T$ - Eu fiquei somente dois anos na primeira vez, no início dos anos 1970. Participei das comemorações dos 2.500 anos do Império Persa, em Persépolis, juntamente com o Ministro Portella e o Embaixador Expedito Rezende, representantes do Presidente Emílio Garrastazu Medici. Fui por acaso porque estavam convidados somente os Chefes de Estado e a realeza europeia e asiática. O Brasil, porém, só mandou dois membros. Acabei indo porque a delegação brasileira ficou muito pequena. Só para você ter uma ideia do fausto das comemorações e do nível dos convidados, na minha mesa de jantar estavam a princesa Anne da Inglaterra, irmã da rainha Elizabeth, a Begun, ex-Miss França que tinha se casado com o Ali Khan. E tinha a princesa Sirikit, da Tailândia. As baixelas eram de ouro. Estava proibida a circulação de dinheiro durante as comemorações em Persépolis, os serviços em geral eram gratuitos para os convidados do Xá. As ruas de Teerã foram decoradas pelas melhores casas da França e eram realizadas durante o dia e destruídas durante a noite pela população revoltada com tanta gastança. Para ir de Teerã a Shiraz o Irã contratou os serviços das melhores companhias de aviação e os passageiros convidados nada pagavam. Tudo era por conta do Xá. Havia entre os convidados quem comentasse: "Será se o Príncipe Herdeiro se sentará no trono ou a monarquia acabará antes?”.

\section{MS - E o que mais o senhor falaria da} cultura persa, que é muito sofisticada?

$S T$ - Eu sei pouco sobre a literatura, mas posso lhe dizer que a literatura turca, que era oral, foi toda escrita em persa. E depois o Império Persa era tão vasto! Englobava parte do Afeganistão (Herat). A capital de verão do Xá era Ctesifonte - Selêucida (Bagdá). A cultura persa sofreu grande influência da cultura heleno-macedônia. Um dos palácios favoritos de Alexandre Magno ficava em Ecbátana, atual Hamadan (Pérsia). Mas o que mais chamou a minha atenção foram os tapetes persas feitos até 1914 e os pratos Compagnie des Indes "Rose de Maomet", que segundo me disseram, vinham da China, mas eram 
pintados no Irã. No Brasil somente o Duque de Caxias possuía um serviço de jantar completo.

\section{$M S$ - E como foi sua relação com os armênios no Irã?}

ST - Bem, aí é melhor eu falar já da República Islâmica do Irã, onde servi como Embaixador no início dos anos 1990. Lá os armênios, como os judeus e os zoroastrianos, por serem monoteístas tem representação no Parlamento. Gozavam de relativa liberdade e eu era frequentemente convidado para solenidades ou em privado. Em nenhum momento notei restrições contra os armênios, à exceção dos sermões durante as missas que não poderiam ser feitos em língua persa. Havia alguns muçulmanos que passaram a frequentar as igrejas armênias e a apostasia no Irã é punida com a pena de morte. Nos restaurantes e clubes armênios as mulheres cristãs em geral e a judias estavam dispensadas do véu islâmico, o que levava o corpo diplomático a frequentá-los com muita frequência. A dança e os acampamentos também eram permitidos. Em Esfahan, por exemplo, a cidade se desenvolveu em dois braços. É lindíssima e aconselho uma visita. Um braço da cidade é armênio e só lá há quatorze igrejas, muitas delas pintadas por pintores da Renascença italiana. O lado muçulmano possui mesquitas lindíssimas e o principal hotel foi construído como se fosse um "caravanserai". Os armênios de Esfahan, que ajudaram a construir a cidade, vieram do sul do Cáucaso, em dois momentos, para ensinar artesanato em geral, e a convite do
Xá Abbas, considerado rei sol da Pérsia pelos historiadores ocidentais. Chamou-me também a atenção as sinagogas e os judeus diziam: Estamos aqui desde sempre, viemos com Esther quando fomos libertados pelos persas do cativeiro na Babilônia". Os Aiatolás temem o sionismo e o Estado de Israel. Mas voltando aos armênios, você sabe que o Irã é aliado da Armênia na guerra contra o Azerbaijão, por causa do enclave armênio de Nagorno-Karabagh ${ }^{6}$, ou Artshah em armênio.

MS - Isso. Eu pediria então para o senhor falar um pouco sobre o Azerbaijão e o Irã.

$S T$ - E isso é interessante porque um país muçulmano numa guerra deve sempre aliarse com o outro país islâmico, que seria no caso com o Azerbaijão, mas o Irã por conveniência se aliou à Armênia. A razão principal que o Azerbaijão, capital Baku, com frequência confronta o Irã com a ameaça de incitar a secessão das regiões iranianas habitadas por azeris. Há 20 milhões de azeris nessas regiões A capital do Azerbaijão iraniano é Tabriz, no noroeste do Irã. Os persas costumam chamar os azeris de turkhar - turco idiota ou burro, expressão jocosa, mas pejorativa quando se referem aos azeris. Embora vale dizer que a dinastia Qajar, que governou o Irã por muito tempo, fosse azeri. Convivi também com alguns deputados armênios que me permitiram conhecer o país com

\footnotetext{
6 Área de maioria armênia localizada em território do Azerbaijão, tem sido uma constante fonte de tensões políticas entre os dois países. [N.E.].
} 


\section{Muralf}

INTERNACIONAL
Mural Internacional

V. 7 | N. 2

JUL-DEZ 2016 mais profundidade. Os árabes em sua política de conquista arabizaram a Síria, o Líbano e a Palestina, mas não conseguiram arabizar o Irã, pois além de sua civilização ser superior à dos ocupantes, eles criaram um ramo herege do Islã, o Xiismo. Antes da conquista árabe do Irã, os persas eram em sua grande maioria zoroastristas - como os armênios - ou cristãos. E o Xiismo foi uma maneira deles preservarem a sua cultura. Para aceitar a nova religião incorporaram muitos aspectos do zoroastrismo e do cristianismo. O xiismo duodecemanita iraniano tem doze imãs como temos doze apóstolos. O quarto imã casou-se com a última princesa sassânida e aí entram elementos do zoroastrismo. O décimo primeiro imã casou-se com a princesa Narkez vinda de Bizâncio, cristã, e aí são incorporados diversos aspectos do cristianismo. E o imã que eles chamam de imã Oculto, que é o imã Mehdi, corresponde ao nosso Divino Espírito Santo. O Papa católico só é assistido pelo Espírito Santo em assuntos de fé. No caso do Irã, o Aiatolá Uzmá, além das questões de fé, também é assistido pelo imã Mehdi na apreciação de certos atos do Legislativo e do Executivo que necessitam da aprovação do líder Supremo. O Xiismo, desse modo, serviu de escudo protetor, evitando que o Irã fosse arabizado, a exemplo da Síria, Sudão ou Argélia, para só citar alguns.

MS - E como os armênios viam o senhor, como um diplomata brasileiro?

$S T$ - Com muito orgulho. Eu até tinha que às vezes que tomar certo cuidado, lembrando-os de que eu era Embaixador do Brasil para todos iranianos. Quando minha missão no Irã foi concluída, como de praxe, o Ministro dos Negócios Estrangeiros oferece um almoço de despedida juntamente com um grupo de Embaixadores Estrangeiros. Fiz a maior parte de meu discurso de despedida em inglês, mas fiz a conclusão em persa. Quando o Ministro iraniano respondeu, encerrou seu discurso com uma mensagem para mim do Presidente Rafsjani: "O senhor é hóspede oficial permanente do Irã. Quando se aposentar fixe sua residência aqui’. E eu respondi: certamente! (risos)

MS - Essa característica do senhor falar a língua e se especializar em Oriente Médio me parecem um caso isolado no MRE. Não houve uma política do Itamaraty em ter especialistas. Eu estou correta?

$S T$ - Sim, está correta. Principalmente nesta época. O Ministério errava muito por falta de conhecimento da região. Mesmo depois de eu ter deixado a região fui constantemente convocado para missões oficiais. Foi o que aconteceu às vésperas da Primeira Guerra do Golfo em 1990. Eu era Cônsul Geral em Assunção e o Itamaraty designou-me para integrar Missão ao Iraque para obter a liberação de 300 brasileiros detidos pelo regime de Saddam Hussein que iriam, com outros estrangeiros, servir de "escudo" quando os Estados Unidos bombardeassem Bagdá. Mesmo os diplomatas que eram de ascendência árabe não queriam ir. A missão negociou por 33 dias, e foi bem-sucedida. 
MS - Quanto tempo o senhor ficou no Iraque?

ST - Eu fiquei quatro anos e meio, de 1980 a 1984. E talvez esteja sem cabelos graças a Israel, porque durante minha permanência em Bagdá, Telavive bombardeou as instalações nucleares de Ozirak. (risos). Estava em Brasília chefiando a Divisão do Oriente Médio, quando meu Chefe me pediu que fizesse uma exposição sobre a região para o General Samuel Alves Correia, designado embaixador do Brasil em Bagdá, quando então fui convidado para integrar sua equipe. Em 1980 era tal a nossa dependência de petróleo importado que as relações com o Iraque tornaram-se muito importantes para o Brasil. O Brasil decidiu nomear Embaixador, Generais, e designar funcionários da instituição correlata à ABIN para assessorá-lo, além de diplomatas.

MS - O que o senhor pode falar dos interesses do Brasil no Iraque?

ST - Algumas empresas brasileiras atuavam no Iraque nas áreas de engenharia civil, armamentos e manutenção. Eram a Engesa, a Avibrás, a Embraer, a Volkswagen e o Grupo do Brigadeiro Piva secundado por engenheiros do ITA. $O$ Iraque era importantíssimo para o Brasil. Foi o primeiro país para o qual o Brasil conseguiu exportar serviços de engenharia e propiciou o desenvolvimento de nossa indústria armamentista com capital iraquiano. Davam recursos e nós executávamos os projetos. Muita coisa foi publicada no Brasil sobre o assunto, algumas boas e algumas incorretas. O livro "Saddam, o amigo do Brasil. A história secreta da conexão Brasil-Bagdá", do jornalista Leonardo Attouche apresenta algumas imprecisões. Há depoimentos, por exemplo, de autoridades brasileiras sobre a retirada dos brasileiros que precedeu a primeira Guerra do Golfo com equívocos. Coube-me, com o Conselheiro René Loncan renegociar todos os contratos assinados pelo Brasil, condição imposta pelos iraquianos para liberar os brasileiros detidos.

MS - O senhor pode falar de como era o contexto da guerra e seus impactos para o Brasil? Há quem diga que o Iraque não honrou com alguns compromissos...

$S T$ - Não é verdade. O Iraque pagou até o último centavo, inclusive em indenizações a pessoas jurídicas e físicas. Houve um funcionário brasileiro que teve sua casa destruída no Kuwait, por conta da invasão do Iraque, e foi indenizado em aproximadamente um milhão de dólares $\mathrm{A}$ empreiteira Mendes Júnior foi integralmente paga. Quem presidiu a comissão em Genebra de ressarcimento e indenizações foi o Embaixador Celso Amorim, melhor informado do que eu. No contexto das sanções impostas ao Iraque, a ONU permitiu que o Iraque vendesse petróleo para pagar suas dívidas. Só para você ter uma ideia da importância das relações do Brasil com o Iraque, só com o petróleo, na ocasião, o Brasil economizou aproximadamente 23 bilhões de dólares. Nossa situação econômica em 1980 era difícil, de penúria de divisa. Nós não tínhamos como pagar nossas importações de petróleo e o Iraque aceitava vender para o Brasil mediante compensação com 


\section{Muralf}

INTERNACIONAL
Mural Internacional

V. 7 | N. 2

JUL-DEZ 2016 importações de bens e serviços. Já o Irã, por exemplo, não vendia petróleo para o Brasil porque preferia vender a preços do mercado spot de Roterdã, bastante mais vantajosos. Importávamos do Iraque 700.000 barris de petróleo por dia. Com a guerra Irã-Iraque, a Arábia Saudita assumiu as obrigações do Iraque e continuou honrando seus compromissos com o Brasil. Isso porque a Arábia Saudita temendo a influência da República Islâmica do Irã na região e considerava que a guerra empreendida pelo Iraque atendia a seus interesses no Golfo Pérsico. Para a Arábia Saudita o Iraque estava fazendo o trabalho "sujo", que ela precisava. Aliás, o problema saudita com o Irã ainda continua.

\section{MS - E como foi sua experiência no Kuwait?}

$S T$ - Lá foi completamente diferente, porque o Kuwait é uma espécie de Estado tampão entre o Irã e os países do Golfo. Mesmo agora o Kuwait não entrou no grupo capitaneado pela Arábia Saudita que decidiu romper relações com o Catar. Sua população autóctone está equilibrada entre xiitas (descendentes de iranianos) e sunitas (descendentes de sauditas). Os sunitas controlam o setor público e os xiitas controlam a economia. Eles não brigam e tentam tirar proveito disso, oscilando entre a Arábia Saudita e o Irã. Servi lá de 1975 a 1978. Retornei diversas vezes ao Oriente Médio em missões especiais de curta duração. Como lhe falei, não havia muita gente preparada. Meu Chefe, Embaixador Marcus Azambuja considerava-me arabista e "iranólogo", o que me parecia exagerado.
MS - Tinham outros embaixadores com esse perfil?

$S T$ - Não. Eu não sei como é agora, mas na época não havia. Não havia lotação de funcionários adequada. Como temos pouquíssimo pessoal preparado para a China. Na França, há diplomatas e oficiais de chancelaria oriundos da École Nationale d'Administration Publique, "Agent pour l'Orient", que servem sempre no Oriente Médio. Os outros funcionários franceses são oriundos do "Le Quai d'Orsay."7.

MS - Quais foram as suas outras missões para o Oriente Médio? O senhor chegou a ir à Israel alguma vez?

$S T$ - Não, nunca oficialmente. Fui como turista a Telavive e Jerusalém. Oficialmente estive em a Argel, Túnis, Cairo, Jedá, Riad, Amã, Damasco, Beirute, Kuwait, Manama, Bagdá, Teerã e Cabul. Eram todas missões oficiais que de curta duração, à exceção de Bagdá, Teerã e Cabul, que na época era embaixada cumulativa com Teerã.

MS - Eram todas ligadas ao petróleo ou a empreiteiras?

ST - Tinha de tudo. Desde libertar brasileiros, missões oficiais de caráter administrativo, em Amã solicitar os bons ofícios de Yasser Arafat junto a Saddam Hussein para a liberação dos brasileiros, etc. até idas a Damasco e a Beirute. Voltei a

\footnotetext{
${ }^{7}$ Quai d’Orsay é a localização em Paris do Ministério das Relações Exteriores da França, e por metonímia, um modo de se referir a essa instituição. [N.E.].
} 
114

Mural Internacional

V. 7 | N. 2

JUL-DEZ 2016
Teerã a serviço também umas cinco ou seis vezes. Fui muitas vezes como chefe da DOP participar de comissões mistas. Eu participei de todas com o Iraque, por exemplo.

MS - Quando o senhor dirigiu a divisão? Era DOMA?

$\boldsymbol{S T}$ - Não, era DOP: Divisão de Oriente Próximo posteriormente desdobrada em DOP I e DOPII, de 1978 a 1980. Eu fui para o Iraque convidado pelo General Samuel Alves Correa, Chefe do EstadoMaior das Forças Armadas, designado Embaixador. De início recusei o convite, pois além de estar no Quadro de Acesso era Chefe de Divisão, o que significava promoção na Carreira por mérito. Isso atrapalharia a minha promoção. Ele respondeu: "Mas você vai e vai promovido". Poucos dias depois o Presidente da República, General Figueiredo, promoveu-me, por mérito, a Conselheiro. Aceitei o convite. Minha turma de Rio Branco formou 26 diplomatas; somente sete chegaram a Embaixador.

MS - Quem eram aqueles que chegaram a embaixadores? O Ademar Bahadian era da sua turma?

$S T$ - Não, mas fomos promovidos no mesmo ano: o Bahadian, em junho e eu, em dezembro. Ele formou-se em março de 1967 e eu, em novembro do mesmo ano. Os outros foram: Carlos Moreira Garcia, Osmar Vladimir Chohfi, José Marcos Vinicius de Souza, José Maurício de
Figueiredo Bustani, Marcus Camacho de Vicenzi e Alexandre Ador Neto.

MS - Já se percebe aí uma presença de filhos de imigrantes, inclusive árabes, não é?

$S T$ - Sim, basta ver os sobrenomes.

MS - Embaixador, o senhor é o primeiro a de fato se especializar em Oriente Médio no Itamaraty. Acha que a origem armênia teve um peso nesta trajetória? E em que medida servindo na região, foi se interessando mais por ela?

$S T$ - Pode ser. Talvez por atavismo, talvez pelos armênios terem ocupado tantos postos de relevância na Carreira diplomática durante o Império Otomano e na União Soviética e na atual Rússia. Ou mesmo um Gulbekian, "Mister 5\%", que representou ora o Império Otomano em Paris ora o Império Persa em Londres, e intermediou as primeiras concessões de petróleo, e daí o "5\%", canalizado para a Fundação Gulbenkian com sede em Lisboa e a serviço da Cultura e Educação. Ou ainda um Anastas Mikoyan, por mais de 30 anos na Presidência da União Soviética. Tudo isso contribui para que eu desejasse exercer um alto cargo público e, desse modo, servir meu país, o Brasil.

MS - E como eles te tratavam por conta do senhor gostar de servir no Oriente Médio?

$S T$ - A primeira reação dos meus melhores amigos foi: "Você está doido" (risos). A primeira reação de meus colegas foi de espanto. "O primeiro posto da carreira 


\section{Muralf}

INTERNACIONAL
Mural Internacional

V. 7 | N. 2

JUL-DEZ 2016
Teerã?" Naquela época servir em postos periféricos era uma capitis diminuto, pois você tinha que estar nos grandes postos para adquirir conhecimento e auferir da experiência dos colegas mais antigos. Os Ministros de Relações Exteriores saem de Genebra, Nova Iorque, Buenos Aires. Mas eu não tive dificuldades para ter meu trabalho reconhecido pelos Chefes da casa e ser promovido. Muitos dos postos em que servi, tornaram-se importantes para o Brasil. Todas as minhas promoções foram por mérito. Fui agraciado com condecorações importantes tanto na Carreira Diplomática quanto na área do Exército e Marinha.

\section{MS - Embaixador, fica claro para mim} que o senhor foi um pioneiro. Na gestão do ministro Celso Amorim, que têm família turca, houve uma ênfase na região e eu queria saber como o senhor acompanhou isso e se eventualmente foi consultado.

ST - Sim, mas minha contribuição foi modesta. Ela foi maior, na época do ministro Saraiva Guerreiro. Tive o prazer de representar o Brasil no ano 2000 ou 2001 em Veneza, no Conselho da Europa, como observador, quando se discutia, entre outras, a questão do enclave de Nagorno-Karabagh, que levou o Azerbaijão e a Armênia a uma guerra que perdura até hoje.

MS- Desde que o senhor se aposentou do Itamaraty, tem lecionado em uma universidade. Como avalia o Oriente Médio desses últimos anos e o interesse acadêmico na região?
$S T$ - Logo que me aposentei e passei a residir em Porto Alegre, eu fui convidado para dar aulas no curso de Relações Internacionais da ESPM-sul (Escola Superior de Propaganda e Marketing), sobre o Oriente Médio, Cerimonial e Protocolo. Iniciei meus trabalhos ali em setembro de 2009. Tem sido uma experiência bastante agradável e gratificante. $\mathrm{O}$ curso não é obrigatório, os alunos participam por iniciativa própria, e ao final do curso recebem um certificado de frequência. A média do número de alunos é de 35. De alguns anos para cá, além dos alunos de RI, tenho recebido os de Administração, Publicidade e Propaganda e neste último trimestre, surpreendentemente, de Design. Noto que muitos deles têm escolhido temas da região para os Trabalhos de Final de Curso. Alguns chegaram mesmo a pedir ao Coordenador para que eu fosse o Orientador. Ademais tenho sido convidado a fazer palestras em cursos de Pós-Graduação em Relações Internacionais, como foi o caso em Florianópolis e na Univates, e nas faculdades de Comunicação, Letras e RI da UFRGS. Falei ainda nos cursos de RI da UNIRITTER, UNISINOS e PUC. Nesta última foi um curso de extensão aberto ao público. Infelizmente sou muito pessimista com relação à paz e consequente estabilidade no Oriente Médio. Bastam relembrar os conflitos, 
guerras e o terrorismo que assolam a região. A guerra na Síria, o conflito Israel-Palestina, o conflito Arábia Saudita- Irã, o DAECH ou seus resquícios agora. Há ainda a Arábia foram alcançados, mas falhas também são perceptíveis.
Saudita e Iêmen, os Curdos, etc. Vislumbro somente a paz num horizonte longínquo em que certamente haverá necessidade de traçar novas fronteiras para alguns países.

\section{Referências}

Alberti, V. (2013). Manual de História Oral. Rio de Janeiro: FGV.

Amorim, C. (2015). Teerã, Ramalá e Doha: memórias da política externa ativa e altiva. São Paulo: Benvirá.

Grün, R. (1992). Negócios \& Famílias: Armênios em São Paulo. São Paulo: Editora Sumaré.

Loureiro, H. de A. C. (2016). Pragmatismo e Humanitarismo: a Política Externa Brasileira e a Causa Armênia (1912-1922). Tese de Doutorado. História, Universidade Estadual Paulista.

Paverchi, S. R. (2015). Memória da diáspora armênia nos relatos de seus descendentes no Brasil e Argentina (cidades São Paulo e Buenos Aires). Tese de Doutorado. PROLAM, Universidade de São Paulo.

Porto, P. B. (2015). "Os primeiros cristãos do mundo: pertencimento religioso e identidade coletiva na diáspora armênia", in: Horizontes Antropológicos. Porto Alegre, ano 21, n. 43, p. 157-182, jan./jun.

Sochaczewski, M. (2017). Do Rio de Janeiro a Istambul: Contrastes e Conexões entre o Brasil e o Império Otomano (1850-1919). Brasília: FUNAG. 